\title{
Karakteristik Komponen Gizi, Antioksidan, dan Respon Organoleptik Bubur Jagung Tradisional Gorontalo dengan Ekstrak Daun Kersen (Muntingia calabura L.)
}

\author{
Nutrient Characteristic, Antioxidant and Organoleptic Respond of Gorontalo Traditional Cornmeal \\ with Cherry Leaves Fortificant (Muntingia calabura L.) \\ Lisna Ahmad*, Suryani Une, Yoyanda Bait \\ Jurusan Ilmu dan Teknologi Pangan, Fakultas Pertanian, Universitas Negeri Gorontalo, \\ Jl. Jenderal Sudirman No. 6 Kota Gorontalo, Indonesia \\ *Email: lisna.ahmad@ung.ac.id
}

Tanggal submisi: 1 Oktober 2017; Tanggal penerimaan: 9 November 2018

\begin{abstract}
ABSTRAK
Tujuan dari penelitian ini adalah menghasilkan bubur jagung yang ditambahkan dengan ekstrak daun kersen yang memiliki aktivitas antioksidan yang tinggi dan diminati konsumen secara organoleptik. Penelitian ini menggunakan rancangan acak lengkap dengan faktor tunggal pada 6 taraf perlakuan yaitu perendaman grits jagung pada ekstrak kersen dengan konsentrasi $0 \%, 10 \%, 20 \%, 30 \%, 40 \%$, dan 50\%. Hasil analisis kandungan gizi terdiri dari protein berkisar antara 7,59-8,93\%, lemak 0,53-0,96, kadar abu 0,05-0,12\%, kadar air 11,59-13,99\% dan kadar karbohidrat by difference $77,24-78,91 \%$. Hasil aktivitas antioksidan menunjukkan bahwa makin tinggi konsentrasi ekstrak daun kersen yang ditambahkan makin tinggi pula aktivitas antioksidan bubur jagung terfortifikasi yaitu $11,85-36,17 \%$ dengan peningkatan dua kali lipat lebih tinggi dari kontrol (tanpa fortifikasi. Berdasarkan uji organoleptik panelis memberikan respon netral sampai agak suka untuk aspek warna, tekstur, aroma dan overall bubur jagung sedangkan untuk aspek rasa panelis memberikan respon agak tidak suka.
\end{abstract}

Kata kunci: Antioksidan; daun kersen; bubur jagung; fortifikasi; organoleptik

\begin{abstract}
Traditional food products are no longer attractive to the public, so it needs innovation to ensure that the products have a functional value. The aim of this research is to produce fortified cornmeal with kersen (Muntingia calabura L.) leaf extract which has high antioxidant activity and consumer demand of organoleptics. This research used a completely randomized design with single factor at 6 treatment levels, soaking grits of corn on cherry extract with $0 \% ; 10 \% ; 20 \% ; 30 \% ; 40 \%$; and $50 \%$ concentrations. The results of nutrient analysis showed that protein contents ranged from $7.59 \%-8.93 \%$; fat $0.53 \%-0.96 \%$; ash content $0.05 \%-0.12 \%$; water content $11.6 \%-13.37 \%$; and carbohydrate $77.24 \%-78.91 \%$. The result of antioxidant activity showed that the higher concentration of kersen leaf extract added the higher also the antioxidant activity of fortified cornmeal, between $11.85-36.17 \%$. Based on panelists' organoleptic test, most gave neutral response to like slightly for color, texture, aroma and overall grits, while for the panelists, while for taste they gave dislike slightly response.
\end{abstract}

Keywords: Antioxidant; cherry leaves; cornmeal; fortification; organoleptic 


\section{PENDAHULUAN}

Bubur jagung tradisional Gorontalo merupakan pangan alternatif yang dijadikan sebagai pengganti bubur beras pada saat sarapan maupun di waktuwaktu tertentu. Konsumen bubur ini lebih didominasi oleh orang dewasa bahkan manula karena teksturnya yang lembut. Selain itu olahan jagung dapat juga dijadikan sebagai pangan alternatif yang baik untuk kesehatan terutama bagi masyarakat yang memiliki potensi kelebihan gula darah (Diabetes mellitus). Hal ini disebabkan oleh jagung merupakan bahan pangan yang jenis karbohidratnya memiliki kandungan indeks glikemik yang rendah sehingga baik untuk kesehatan. Indeks glikemik jagung dalam bentuk jagung rebus adalah $60 \mathrm{mg} / \mathrm{g}$ bahan. Nilai ini termasuk nilai indeks glikemik sedang dibanding kandungan indeks glikemik nasi putih yaitu $89 \mathrm{mg} / \mathrm{g}$ bahan yang sudah termasuk bahan berindeks glikemik tinggi (Regina 2012). Hasil penelitian Amalia dkk. (2011) menunjukkan bahwa hasil pengukuran respon glikemik menunjukkan bahwa jagung manis rebus dan tumis memiliki nilai indeks glikemik (IG) masing-masing sebesar 41,22 dan 31,08 dan termasuk pangan kategori IG rendah. Jagung manis bakar memiliki indeks glikemik sebesar 55,31 dan termasuk ke dalam kategori pangan dengan IG sedang. Hasil analisis ragam menunjukan bahwa pengolahan tidak mempengaruhi nilai IG.

Komposisi kimia bubur jagung mengacu pada komponen kimia jagung, karena proses pembuatan bubur jagung umumnya dengan metode pengecilan ukuran yang selanjutnya dimasak dalam air yang banyak sampai grits jagung matang. Penambahan ekstrak daun kersen diharapkan dapat lebih aktif menekan penyerapan kadar gula dalam darah sehingga meningkatkan indeks glikemik penderita Diabetes mellitus (DM). Menurut Suhardjono (2015) bahwa daun kersen mengandung saponin serta flavonoid yang berperan sebagai antioksidan sehingga mampu menyekresi hormon insulin yang dibutuhkan oleh tubuh untuk metabolisme gula. Begitu pula yang disampaikan Naim (2004) dalam Prasetyo dan Sasongko (2014) bahwa daun kersen mengandung flavonoid, tanin, glikosida, saponin, steroid, dan minyak esensial.

Hasil penelitian Arum dkk. (2012), menunjukkan bahwa ekstrak hasil isolasi daun kersen merupakan senyawa flavanoid berupa auron, flavanol dan flavon. Senyawa flavanoid pada daun kersen diyakini oleh masyarakat umum dapat digunakan sebagai obat DM. Hal ini dapat dibuktikan melalui penelitian yang dilakukan oleh Sridhar dkk. (2011), yang mana ekstrak daun kersen dapat secara signifikan memiliki aktivitas antidiabetes pada tikus yang diinduksi dengan aloksan.
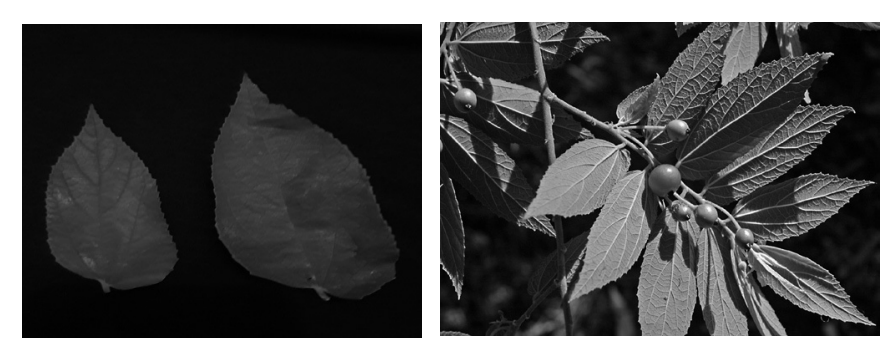

Gambar 1. Gambar daun kersen (Muntingia calabura L)

Pada penelitian ini jumlah ekstrak daun kersen yang diberikan yaitu 300 dan $500 \mathrm{mg} / \mathrm{kg}$ berat badan tikus. Penelitian serupa telah dilakukan oleh Aruna dkk. (2013), menunjukkan bahwa ekstrak daun kersen memiliki aktivitas antioksidan dan antihiperglikemik pada tikus yang diinduksi dengan streptozotocin. Jumlah ekstrak daun kersen yang diberikan yaitu $250-1000 \mathrm{mg} / \mathrm{kg}$ berat badan tikus.

Komposisi kimia daun kersen segar per $100 \mathrm{~g}$ secara lengkap menurut Laswati dkk. (2017) terdiri dari kadar abu 5,08\%, kadar lemak 1,10\%, kadar protein 2,99\%, kadar karbohidrat 28,76\%, kadar air 68,33\%, dan kadar serat $49,60 \%$. Gambar daun kersen dapat dilihat pada Gambar 1.

Penambahan ekstrak daun kersen kemungkinan akan mempengaruhi karakter mutu organoleptik bubur jagung. Oleh sebab itu dalam kajian ini profil mutu yang disukai oleh konsumen akan disajikan sebagai data profil mutu organoleptik bubur jagung.

\section{METODE PENELITIAN}

\section{Bahan}

Jagung yang digunakan dalam penelitian ini diperoleh dari pasar tradisional di Kota Gorontalo dengan varietas Motoro kiki. Daun kersen dipetik dari beberapa pohon yang tumbuh liar di pinggir jalan wilayah Kota Gorontalo dan dipilih yang telah berwarna hijau tua.

\section{Alat}

Alat yang digunakan untuk analisa Antioksidan dengan metode (1,1-diphenyl-2-picrylhydrazyl) DPPH menggunakan Spektrofotometer UV-Vis (Santorius, Jerman) pada panjang gelombang $517 \mathrm{~nm}$. Untuk peralatan profil mutu organoleptik menggunakan wadah-wadah uji berupa piring dari bahan keramik dan sendok stainless steel.

Rancangan penelitian yang digunakan adalah Rancangan Acak Lengkap dengan 1 perlakuan dan 6 taraf yaitu konsentrasi ekstrak daun kersen $0 \%, 10 \%$, $20 \%, 30 \%, 40 \%$, dan $50 \%$. Analisis sampel dilakukan antara lain komponen gizi berupa kadar proksimat, 
aktifitas antioksidan, dan uji organoleptik menggunakan 30 orang panelis semi terlatih dengan tingkat skala 1 - 7 (Sangat tidak suka, tidak suka, agak tidak suka, netral/biasa, agak suka, suka dan sangat suka). Variabel terikat pada uji organoleptik meliputi warna, rasa, aroma, tekstur, dan penampakan keseluruhan

\section{Metode Penelitian}

Penelitian ini diawali dengan pembuatan grits jagung menggunakan hammer mill dan disc mill dengan ukuran 60 mesh. Bersamaan dengan itu dilakukan juga ekstraksi daun kersen dengan metode maserasi yang menggunakan air sebagai pelarut. Grits jagung yang sudah tersedia selanjutnya direndam dalam masingmasing konsentrasi ekstrak daun kersen selama 12 jam. Grits jagung yang telah direndam selanjutnya ditirskan, dicuci dan dikeringkan.

\section{Metode Analisis Proksimat dan Antioksidan}

Analisa kandungan nutrisi pada grits jagung yang dilakukan adalah analisa kadar air, kadar protein, kadar lemak, kadar abu dan kadar karbohidrat by difference (AOAC, 2007). Pada analisis antioksidan menggunakan nilai $\mathrm{EC}_{50}$. Penentuan Nilai EC ${ }_{50}$ Parameter yang digunakan untuk menunjukkan aktivitas antioksidan menggunakan harga konsentrasi efisien $\left(\mathrm{EC}_{50}\right) . \mathrm{EC}_{50}$ adalah bilangan yang menunjukkan konsentrasi ekstrak $(\mu \mathrm{g} / \mathrm{mL})$ yang mampu meredam radikal bebas DPPH sebesar 50\%. Semakin kecil nilai $\mathrm{EC}_{50}$ maka semakin tinggi aktivitas antioksidan. Secara spesifik, suatu senyawa dikatakan sebagai antioksidan sangat kuat jika nilai $\mathrm{EC}_{50}$ kurang dari 50, kuat untuk $\mathrm{EC}_{50}$ bernilai $51-100$, sedang jika $\mathrm{EC}_{50}$ bernilai $101-150$ dan lemah adalah 151 200. Menentukan nilai $\mathrm{EC}_{50}$ untuk mengetahui berapa besar konsentrasi dari ekstrak daun kersen untuk dapat meredam radikal bebas DPPH sebesar 50\%.

\section{HASIL DAN PEMBAHASAN}

\section{Hasil Uji Proksimat}

Kadar proksimat bubur jagung yang difortifikasi dengan daun kersen dapat dilihat pada Tabel 1.

Hasil analisis proksimat menunjukkan bahwa perlakuan penambahan ekstrak daun kersen menghasilkan komponen proksimat bubur jagung berbeda untuk setiap parameter proksimat. Kadar air bubur jagung yang memperoleh ekstrak daun kersen $50 \%$ merupakan nilai tertinggi (14\%) dan secara statistik berbeda nyata dengan perlakuan lainnya. Hal ini kemungkinan disebabkan oleh adanya proses absorpsi ekstrak kersen kedalam granula grits jagung. Alamsyah (2015) menyatakan bahwa salah satu faktor yang mempengaruhi proses absorpsi adalah jenis adsorbat (jenis, kepolaran adsorbat, jenis ikatan, ukuran adsorbat, viskositas campuran). Tingginya konsentrasi ekstrak kersen pada perlakuan 50\% kemungkinan menyebabakan tekanan yang lebih tinggi kepermukaan grits sehingga lebih banyak air yang masuk ke dalam grits jagung. Komponen proksimat lainnya adalah kadar abu yang menghasilkan kisaran nilai dari 0,05-0,12\%. Menurut Nurhasanah (2016) hal ini disebabkan oleh kandungan mineral yang terdapat pada daun kersen seperti fosfor, kalsium. Lebih lanjut Hely dkk. (2018) menjelaskan kandungan mineral yang terdapat dalam daun kersen yaitu kalsium dan mangan. Kadar protein cenderung mengalami penurunan ketika konsentrasi ekstrak kersen meningkat. Hal ini berkorelasi negatif dengan kadar air karena sebagian protein akan hilang akibat masuknya sejumlah air dalam granula pada saat perendaman sehingga kemungkinan komponen protein terlarut yang terdapat dalam granula akan ikut larut dan ikut terbuang ketika air perendamnya dibuang. Kadar

Tabel 1. Kadar proksimat bubur jagung yang difortifikasi ekstrak daun kersen

\begin{tabular}{cccccc}
\hline $\begin{array}{c}\text { Konsentrasi } \\
\text { ekstrak (\%) }\end{array}$ & Air & Abu & Protein & Lemak & Karbohidrat \\
\hline 0 & $13,29 \pm 0,02^{\mathrm{d}}$ & $0,07 \pm 0,00^{\mathrm{b}}$ & $8,38 \pm 0,11^{\mathrm{b}}$ & $0,74 \pm 0,00^{\mathrm{abc}}$ & $77,46 \pm 0,13^{\mathrm{a}}$ \\
10 & $13,37 \pm 0,08^{\mathrm{d}}$ & $0,10 \pm 0,00^{\mathrm{c}}$ & $8,51 \pm 0,17^{\mathrm{b}}$ & $0,76 \pm 0,01^{\mathrm{bc}}$ & $77,24 \pm 0,25^{\mathrm{a}}$ \\
20 & $11,59 \pm 0,08^{\mathrm{a}}$ & $0,12 \pm 0,01^{\mathrm{c}}$ & $8,93 \pm 0,18^{\mathrm{c}}$ & $0,76 \pm 0,09^{\mathrm{bc}}$ & $77,48 \pm 0,35^{\mathrm{a}}$ \\
30 & $11,8 \pm 0,002^{\mathrm{b}}$ & $0,12 \pm 0,00^{\mathrm{c}}$ & $8,38 \pm 0,15^{\mathrm{b}}$ & $0,65 \pm 0,16^{\mathrm{ab}}$ & $78,84 \pm 0,28^{\mathrm{b}}$ \\
40 & $12,96 \pm 0,03^{\mathrm{c}}$ & $0,05 \pm 0,00^{\mathrm{ab}}$ & $7,79 \pm 0,06^{\mathrm{a}}$ & $0,96 \pm 0,09^{\mathrm{c}}$ & $78,90 \pm 0,03^{\mathrm{b}}$ \\
50 & $13,99 \pm 0,04^{\mathrm{e}}$ & $0,05 \pm 0,00^{\mathrm{ab}}$ & $7,59 \pm 0,01^{\mathrm{a}}$ & $0,53 \pm 0,01^{\mathrm{a}}$ & $78,38 \pm 0,04^{\mathrm{b}}$ \\
\hline
\end{tabular}

Keterangan: Notasi huruf yang sama menunjukkan tidak beda nyata pada a $=0.05$. Data disajikan \pm standard deviasi. 
lemak dan kadar karbohidrat berada pada kisaran 0,53 $-0,96 \%$ dan $77,24-78,9 \%$ masing-masing.

\section{Hasil Uji Organoleptik}

Bubur jagung instan yang difortifikasi ekstrak daun kersen yang dihasilkan dianalisis parameter organoleptiknya dengan menggunakan uji hedonik dan komponen antioksidan. Uji hedonik dilakukan oleh 30 orang panelis semi terlatih terhadap bubur yang dihasilkan. Panelis diminta tanggapan pribadinya mengenai kesukaan atau ketidaksukaannya pada produk bubur. Skala hedonik yang diberikan dapat diinterpretasikan menjadi skala numerik dengan angka mutu menurut tingkat kesukaan. Data numerik yang dihasilkan dapat dianalisis secara parametrik (Setyaningsih dkk., 2010).

\section{Warna}

Warna merupakan parameter penting yang menentukan tingkat kesukaan dan penerimaan panelis terhadap suatu produk. Hasil uji hedonik terhadap warna bubur jagung dapat dilihat pada Tabel 1. Hasil uji hedonik terhadap warna bubur jagung fortifikasi mendapat penilaian netral dan agak suka dari panelis dengan kisaran nilai antara 4,3-5,4 atau netral/biasa - agak suka. Warna yang dihasilkan dari bubur jagung tanpa ekstrak daun kersen mendapatkan penilaian tertinggi dari panelis dengan nilai 5,4 yang berarti panelis agak suka dengan sampel bubur jagung. Fortifikasi grits jagung dengan ekstrak daun kersen tidak memberikan perubahan warna pada semua sampel perlakuan.

Warna bubur jagung diperoleh dari senyawa yang umumnya secara alami terdapat pada daun berupa klorofil (Huda dkk., 2015). Semakin banyak konsentrasi ekstrak daun kersen yang dijadikan sebagai bahan fortifikan, warna grits bubur jagung semakin gelap sehingga rata-rata penilaian konsumen hanya mencapai skala agak suka.

\section{Rasa}

Rasa merupakan atribut mutu yang penting dalam menentukan penerimaan konsumen terhadap produk tertentu. Respon panelis terhadap rasa bubur jagung yang terfortifikasi yaitu dari netral sampai agak suka dengan skala 3,5-4,6. Bubur jagung dengan konsentrasi $20 \%$ ekstrak daun kersen mendapatkan respon agak tidak suka dari aspek rasanya. Sedangkan pada perlakuan bubur jagung tanpa penambahan ekstrak daun kersen mendapatkan respon netral dari panelis. Respon ketidaksukaan panelis terhadap rasa bubur terfortifikasi dipengaruhi oleh rasa ekstrak daun kersen yang memberikan rasa cenderung pahit dan sepat.

Menurut Zakaria (2011) dalam Laswati dkk. (2017) bahwa daun kersen mengandung falvonoid, tannin, triterpenoid, saponin, polifenol dan lain-lain. Komponen senyawa ini adalah kompnen yang berkontribusi terhadap rasa bubur jagung sehingga konsumen memberikan skala penilaian sampai pada skala netral yang berarti antara tidak suka dan suka.

\section{Tekstur}

Tekstur adalah salah satu sifat produk yang dapat dirasakan melalui sentuhan kulit ataupun pencicipan. Tekstur yang dimiliki oleh suatu produk mempengaruhi mutu produk yang akhirnya mempengaruhi penerimaan konsumen terhadap produk tersebut. Hasil penilaian tingkat kesukaan panelis terhadap tekstur bubur jagung terfortifikasi dapat dilihat pada Tabel 1. Hasil uji hedonik tekstur bubur jagung yang difortifikasi ekstrak daun kersen menunjukkan bahwa panelis memberikan respon netral sampai agak suka dengan skala 4,1-4,9.

\section{Aroma}

Aroma merupakan salah satu indikator penting dalam pengujian organoleptik karena aroma dapat menentukan penerimaan panelis terhadap suatu produk. Hasil penilaian panelis terhadap aroma bubur jagung terfortifikasi dapat dilihat pada Tabel 1 . Hasil uji hedonik tingkat kesukaan panelis terhadap aroma bubur jagung mendapatkan respon yang sama yaitu netral hingga agak suka dengan nilai antara 4,3-4,7. Aroma ekstrak daun kersen memiliki aroma yang khas daun kersen dimana Menurut Manik dkk. (2014) bahwa aroma yang berasal dari daun kersen dihasilkan dari senyawa flavonoid, tannin, dan alkaloid.

\section{Overall}

Penilaian panelis terhadap keseluruhan bubur jagung berkisar antara 4,4 - 5,2. Hal ini menunjukkan bahwa secara keseluruhan bubur jagung terfortifikasi ekstrak daun kersen mendapatkan respon

Tabel 2. Hasil analisis uji hedonik

\begin{tabular}{cccccc}
\hline $\begin{array}{c}\text { Konsentrasi } \\
\text { ekstrak } \\
(\%)\end{array}$ & Warna & Rasa & Tekstur & Aroma & Overall \\
\hline 0 & 5,4 & 4,6 & 4,7 & 4,6 & 5,2 \\
10 & 4,9 & 4,5 & 4,9 & 4,6 & 5,1 \\
20 & 4,3 & 3,5 & 4,1 & 4,3 & 4,4 \\
30 & 4,8 & 4,4 & 4,4 & 4,5 & 5,0 \\
40 & 4,7 & 4,5 & 4,5 & 4,7 & 4,3 \\
50 & 4,3 & 4,5 & 4,5 & 4,6 & 4,7 \\
\hline
\end{tabular}


panelis netral dan agak suka (Tabel 2). Perlakuan fortifikasi ekstrak daun kersen terhadap grits dengan berbagai konsentrasi tidak mempengaruhi tingkat penerimaan panelis terhadap keseluruhan produk.

\section{Aktivitas Antioksidan}

Aktivitas antioksidan merupakan kemampuan suatu senyawa untuk menghambat terjadinya reaksi oksidasi yang dinyatakan dengan persentase penangkapan radikal bebas. Aktivitas antioksidan bubur terfortifikasi dapat dilihat pada Tabel 3.

Aktivitas antioksidan bubur terfortifikasi meningkat seiring dengan meningkatnya konsentrasi esktrak daun kersen yang ditambahkan. Peningkatan aktivitas antioksidan menunjukkan adanya donor hidrogen dari komponen ekstrak daun kersen sehingga menurunkan intensitas warna ungu pada larutan DPPH. Penurunan intensitas warna DPPH menunjukkan bahwa terjadi penangkapan radikal DPPH oleh sampel yang mengakibatkan berkurangnya ikatan rangkap diazo pada DPPH (Zuhra dkk., 2008). Menurut Dewi (2013), ekstrak daun kersen mengandung flavonoid, tanin dan terpenoid dengan fraksi yang mengandung antioksidan adalah golongan senyawa tanin.

\section{KESIMPULAN}

Fortifikasi bubur jagung dengan ekstrak daun kersen dilihat dari aspek warna berada pada kisaran skor 4,3-5,4 (netral - agak suka), tekstur kisaran skor 4,1 - 4,9 (netral - agak suka), aroma dengan kisaran skor 4,3-4,7 (netral - agak suka) dan keseluruhan (overall) dengan kisaran skor 4,3-5,2 (netral - agak suka). Pada aspek rasa berdasarkan rata-rata skor hedonik yang diperoleh respon ketidaksukaan panelis terhadap rasa bubur terfortifikasi dipengaruhi oleh rasa

Tabel 3. Aktifitas antioksidan bubur jagung difortifikasi ekstrak daun kersen

\begin{tabular}{cc}
\hline $\begin{array}{c}\text { Konsentrasi } \\
\text { ekstrak }(\%)\end{array}$ & $\begin{array}{c}\text { Kadar antioksidan } \\
\text { value }(\mathrm{mg} / \mathrm{mL}) \mathrm{DPPH}\end{array}$ \\
\hline 0 & $11,85 \pm 0,20^{\mathrm{a}}$ \\
10 & $14,31 \pm 0,19^{\mathrm{b}}$ \\
20 & $17,66 \pm 0,13^{\mathrm{c}}$ \\
30 & $26,06 \pm 0,14^{\mathrm{d}}$ \\
40 & $27,24 \pm 0,06^{\mathrm{e}}$ \\
50 & $36,17 \pm 0,26^{\mathrm{f}}$ \\
\hline
\end{tabular}

Keterangan: Notasi huruf yang sama menunjukkan tidak beda nyata pada $a=0.05$. Data disajikan \pm standard deviasi ekstrak daun kersen yang cenderung pahit. Komponen proksimat bubur jagung terfortifikasi ekstrak daun kersen mengalami perubahan yaitu kadar air meningkat seiring meningkatnya konsentrasi ekstrak daun kersen yaitu sebesar 5,26\% dari kontrol. Kadar abu pada grits jagung menunjukkan adanya mineral dalam bubur jagung terfortifikasi. Kadar protein berkorelasi negatif dengan kadar air. Aktivitas antioksidan bubur terfortifikasi meningkat lebih dari dua kali lipat bubur jagung tanpa perlakuan fortifikasi $(205,23 \%)$

\section{UCAPAN TERIMA KASIH}

Ucapan terima kasih terutama ditujukan kepada pemberi dana penelitian atau donatur. Ucapan terima kasih dapat juga disampaikan kepada pihak-pihak yang membantu pelaksanaan penelitian.

\section{DAFTAR PUSTAKA}

[AOAC] Association of Official Analytical Chemists. 2007. Official Methods of Analysis of AOAC International. 18th Edition. Gaithersburg: AOAC International.

Alamsyah, Z. (2015). Kinetika Adsorpsi 2. https://www. slideshare.net/chiepoey/kinetika-adsorpsi-2. disitasi Minggu 25 Februari 2019.

Amalia, S. N., Rimbawan, \& Mira Dewi (2011). Nilai indeks glikemik beberapa jenis pengolahan jagung manis (Zea mays saccharata Sturt). Jurnal Pangan dan Gizi, 6(1):36-41.

Arum, Y. P., Supartono, \& Sudarmin (2012). Isolasi dan Uji Daya Anti Mikroba Ekstrak Daun Kersen (Mutingia calabura), Jurnal MIPA, 35(2): 165-174 (2012). http:// journal.unnes.ac.id/sju/index.php/jm.

Aruna, S. M., Yadav, D. Bodke., \& Chandrasekar A. (2013). Antioxidant and invivo anty-hypergycemic of Mutingia calabura leaves extracts, Der Pharmacia Lettre, 5(3):427$435 \mathrm{http}: / /$ scholarsresearchlibrary.com/archive.html).

Dewi, Ega T. (2013). Fraksinasi dan Identifikasi Senyawa Antioksidan pada Ekstrak Etanol Daun Kersen (Muntingia calabura $L$ ) secara Kolom Kromatografi. Skripsi. Fakultas Farmasi. Unika Widya Mandala. Surabaya.

Huda, S., Sahputra, A., Anggono, W.A., \& Wahyuni, R. (2015). Pemanfaatan Daun Kersen (Mutingia calabura) Sebagai Permen Jelly Terhadap Daya Terima Konsumen. Program Studi ITP Fakultas Pertanian Universitas YudhartaPasuruan. Jurnal Teknologi Pangan, 6(1): 1218.

Laswati, D. T., Natalia, R. I. S., \& Oktiva A. (2017). Pemanfaatan Kersen (Muntingia Calabura L.) Sebagai Alternatif Produk Olahan Pangan: Sifat Kimia dan Sensoris. Jurnal JITIPARI, UNISRI Surakarta, 4:127-134. 
Manik, D. F., Triana, H., \& Hadi, A. (2014). Analisis Korelasi Antara Kadar Flavonoid dengan Aktifitas Antibakteri Ekstrak Etanol dan Fraksi-fraksi Daun Kersen (Mutingia calabura) terhadap Staphylococcus aureus. Jurnal Khazanah, 6(2): 1-11.

Nurhasanah, N. (2016). Isolation of Antioxidant Compound of Muntinga Calabura Linn Leave. https://www. researchgate.net/publication/291813987. DOI: 10.13140/RG.2.1.1112.1687.

Pramono dan Santoso (2014). Pengaruh ekstrak buah kersen (Mutingia calabura) terhadap kadar gula darah tikus putih (Rattus norvegicus) yang diinduksi oleh Streptozotocin (STZ), JSV,32(2) : 218-223.

Prasetyo, A. D., \& Hadi, S. (2014). Aktivitas antibakteri ektrak etanol 70\% daun kersen (Mutingia calabura) terhadap bakteri Bacillus subtilis dan Shigella dysenteriae sebagai materi pembelajaran Biologi SMA Kelas X untuk mencapai kd 3,4 pada kurikulum 2013, JUPEMASI-PBIO, 1(1): 98-102
Regina (2012). Daftar indeks glikemik makanan. http:// diabetesmelitus.org. [diakses 20 Maret 2017].

Setyaningsih, D., Anton A., Maya, P. S. (2010). Analisis Sensori untuk Industri Pangan dan Agro. IPB Press. Bogor.

Sridhar M., Thirupathi, K., Chaitanya, G., Khrisna M., dan Rabi, K. (2011). Antidiabetic effect of leaves of Mutingia calabura L., ini normal and alloxan-induced diabetic rats, Pharmacologyonline, 2: 626-632.

Zahtamal, Fifia, C., Suyanto, \& Tuti, R. (2007). Faktor-faktor resiko pasien diabetes mellitus, Berita Kedokteran Masyarakat, 23(3): 142-147.

Zuhra, Cut, F., Julianti B. T., \& Herlince, S. (2008). Aktivitas Antioksidan Senyawa Flavonoid dari Daun Katuk (Sauropus androgunus (L) Merr). Jurnal Biologi Sumatera, 3:7-10. 